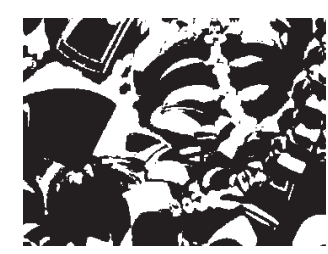

\title{
OVISNOST O VJEŽBANJU - DOPRINOS PERFEKCIONIZMA I ODSTUPAJUĆIH NAVIKA HRANJENJA
}

Ivana GARILOVIĆ

Odjel liudskih resursa, Kutjevo d.d., Kutjevo

Ivana MACUKA

Odjel za psihologiju, Sveučilište u Zadru, Zadar

UDK: $796.012 .6: 178.9$

613.2:178.9

Izvorni znanstveni rad

Primljeno: 22. 7. 2017.

Unatoč pozitivnim doprinosima koje vježbanje ima na tjelesno i psihičko zdravlie pojedinca, u novije vrijeme govori se i o negativnim trendovima tzv. ovisnosti o viežbanju. Ovisnost o vježbanju odnosi se na nekontroliranu potrebu za viežbanjem, pri čemu zadovoljavanje te potrebe postaje glavni cilj u svakodnevnom životu te prestaje biti zdrava navika. U radu je prikazana validacija Skale ovisnosti o viežbanju (Hausenblas i Symon Downs, 2002b), koja je prvi put primijenjena za procjenu prisutnosti simptoma ovisnosti o viežbanju u Hrvatskoj. U istraživanju je sudjelovala 281 sudionica prosiečne dobi od 22 godine $(S D=2,70)$, a podaci su prikuplieni online upitnikom. Cili ovog istraživanja bio je ispitati relativan doprinos perfekcionizma i navika hranjenja u objašnjenju simptoma ovisnosti o vježbanju. Ispitivanjem zasebnih doprinosa dimenzija perfekcionizma i odstupajućih navika hranjenja utvrđeno je da su značajni samostalni prediktori ovisnosti o vježbanju osobni standardi i sumnja u vlastitu izvedbu te dijeta. Preciznije, sudionice koje teže višim osobnim standardima više sumnjaju u vlastitu izvedbu te su sklonije držanju dijete iskazuju više simptoma ovisnosti o vježbanju. Mierene dimenzije perfekcionizma i odstupajućih navika hranjenja pridonijele su objašnjenju $23 \%$ varijance ovisnosti o vježbanju.

Ključne riječi: ovisnost o vježbanju, perfekcionizam, odstupajuće navike hranjenja

$\triangle$ Ivana Macuka, Sveučilište u Zadru, Odjel za psihologiju, Obala kralja Petra Krešimira IV, br. 2, 23000 Zadar, Hrvatska. E-mail: ivana.moranduzzo@unizd.hr 
Vježbanje se odnosi na tjelesnu aktivnost koja je planirana, strukturirana, repetitivna te joj je svrha unapređenje ili održavanje jedne komponente ili više komponenata tjelesne kondicije, a nedvojbeno služi zdravlju - i tjelesnom i psihičkom. Za osobe između 18 i 65 godina preporučeno je vježbanje u trajanju od najmanje 30 minuta umjereno intenzivne aerobne tjelesne aktivnosti (poput brza hodanja) pet puta tjedno ili 20 minuta visoko intenzivne aerobne tjelesne aktivnosti tri puta tjedno (Haskell i sur., 2007). Iako su u javnosti prisutniji zabrinjavajući podaci o negativnim posljedicama sjedilačkoga načina suvremenoga života, činjenica jest da i vježbanje može postati problematično. Stanje u kojemu osoba koja se redovito bavi vježbanjem gubi kontrolu nad svojim ponašanjem te vježbanje postaje kompulzivno i dovodi do negativnih posljedica za zdravlje i svakodnevno funkcioniranje naziva se ovisnost o vježbanju (Szabo, Griffiths i Demetrovics, 2016).

U definiranju ovisnosti o vježbanju najjasnije kriterije predlaže De Coverley Veale (1995), koji ovisnost o vježbanju operacionalizira kao višedimenzionalni neadaptivni obrazac vježbanja koji dovodi do klinički osjetnoga pogoršanja ili emocionalne uznemirenosti. Po njegovu mišljenju, ovisnost se manifestira u najmanje tri od sljedećih pokazatelja: (1) toleranciji koja označuje potrebu za znatnim povećanjem količine vježbanja kako bi se postigao željeni učinak, (2) sustezanju (apstinenciji) i pojavi anksioznosti ili iscrpljenosti u slučaju izostanka vježbanja, (3) efektima namjere, u kojima se vježbanje često odrađuje u većoj mjeri ili kroz dulje razdoblje nego što je bilo planirano, (4) nedostatku kontrole, tj. pojavi stalne želje ili neuspješnih pokušaja smanjivanja ili barem kontrole vježbanja, (5) utrošenom vremenu, odnosno velik dio vremena provodi se $u$ aktivnostima povezanima s vježbanjem, (6) sukobu, tj. odricanju važnih društvenih, profesionalnih ili rekreacijskih aktivnosti u korist vježbanja, (7) kontinuitetu, vježbanje se ne prekida ni kad je pojedinac svjestan trajnih ili ponovljenih fizičkih ili psihičkih problema koji su vrlo vjerojatno izazvani ili potpomognuti prekomjernim vježbanjem (npr. neprekinuto trčanje unatoč ozbiljnim ozljedama noge).

Stopa prevalencije ovisnosti o vježbanju utvrđena na reprezentativnom uzorku opće populacije prilično je niska te varira između 0,3 \% i 0,5 \% (Mónok i sur., 2012). Istraživanja na specifičnijim uzorcima rezultirala su većim vrijednostima, pa je tako među studentima utvrđeno između $3,4 \%$ i 13,4 \% osoba ovisnih o vježbanju (Hausenblas i Symons Downs, 2002a). Među fizički aktivnijim skupinama još je veći udio osoba koje iskazuju ovisnost o vježbanju, u istraživanjima se navode prevalencijski podaci od 33,2 \% kod atletičara amatera (Modoio i sur., 
DRUŠ. ISTRAŽ. ZAGREB GOD. 27 (2018), BR. 4 STR. $713-733$

GARILOVIĆ, I., MACUKA, I.: OVISNOST O...
2011), $42 \%$ kod korisnika teretana (Lejoyeux, Avril, Richoux, Embouazza i Nivoli, 2008) te čak $52 \%$ kod triatlonaca (Blaydon i Lindner, 2002). Razni prevalencijski podaci odraz su razlika u karakteristikama uzoraka, ali i upotrijebljenih mjernih instrumenata. Važno je istaknuti činjenicu kako je stopa prevalencije ovisnosti o vježbanju učestalija kod osoba s poremećajem hranjenja, koje vježbanje rabe kako bi kontrolirale tjelesnu težinu (Bratland-Sanda i sur., 2010).

Među teorijskim pristupima koji nude objašnjenja etioloških čimbenika ovisnosti o vježbanju svojom praktičnom važnošću ističe se model stadija ovisnosti o vježbanju (Freimuth, 2008). U okviru ovoga modela ističu se pitanja kako razlikovati vježbače koji su ovisni i one koji samo puno vježbaju te kako odrediti trenutak $\mathrm{u}$ kojemu predano vježbanje, koje ima pozitivne učinke na zdravlje, prelazi u ovisnost. Freimuth je (2008) kliničkim istraživanjem razlučila ovisnost o vježbanju u četiri faze te dala znatan doprinos u utvrđivanju razlika između rekreacijskoga vježbanja i ovisnosti o vježbanju. Stoga će se njezin model detaljnije opisati $u$ radu zbog njegove korisnosti $u$ istraživačkom dijelu ovisnosti o vježbanju, ali i za kliničku praksu. Svaku fazu unutar modela čine tri komponente prema kojima se razlikuju rekreacijski vježbači od ovisnih, a to su motivacija, posljedice i učestalost, tj. kontrola (Freimuth, Moniz i Kim, 2011).

\section{Prva faza: rekreacijsko vježbanje}

Rekreacijsko vježbanje predstavlja ugodnu i nagrađujuću aktivnost, a izvori motivacije $\mathrm{u}$ ovom stadiju mogu biti promjene u snazi i tjelesnom izgledu postignute vježbanjem, zdravlje i kondicija. Ponašanje je pod kontrolom, što znači da pojedinac prati svoj uobičajeni raspored i može prestati s vježbanjem u planirano vrijeme. Rekreacijsko vježbanje rijetko rezultira negativnim posljedicama, a ako do njih dođe, uglavnom se radi o izravnim posljedicama samoga vježbanja (npr. upaljen mišić, uganut gležanj i sl.) (Freimuth i sur., 2011).

\section{Druga faza: rizično vježbanje}

Iako intrinzična motivacija koja pokreće rekreacijsko vježbanje pozitivno utječe na pojedinca, spoznavanje kako se vježbanjem kontrolira raspoloženje može usmjeriti vježbanje u krivom smjeru. Odnosno, vježbanje se povezuje s povećanjem pozitivnog afekta (npr. podiže samopoštovanje) i smanjivanjem negativnog afekta (npr. depresije i anksioznosti). Razvijanju ovisnosti o vježbanju izloženiji su pojedinci kojima je motivacija bijeg od neugodnih osjećaja ili mijenjanje izgleda kako bi poboljšali samopoštovanje, u odnosu na one koji vježbaju kako bi poboljšali svoju izvedbu i kondiciju. Jedan od znakova prijelaza iz rizične faze $\mathrm{u}$ fazu rane ovisnosti jest povremeni gubitak kon- 
trole nad ponašanjem (u ovom slučaju vježbanjem) koje traje dulje ili je intenzivnije. Negativne posljedice u ovoj fazi pojavljuju se sve češće te su uglavnom izazvane vježbanjem (Freimuth i sur., 2011).

\section{Treća faza: problematično vježbanje}

U ovom stadiju vježbanje polako preuzima glavnu ulogu u svakodnevnom životu osobe. Rutine vježbanja postaju sve strože, pa se druge životne obveze organiziraju prema vježbanju. Pojavljuju se i tzv. sekundarne negativne posljedice koje se odnose na vlastitu i/ili tuđu reakciju na štetne efekte vježbanja (npr. javljanje osjećaja ljutnje zbog ozljede koja sprječava daljnje vježbanje ili prigovaranje prijatelja kako osoba zbog vježbanja nema vremena za druženje). Pojava simptoma sustezanja prilikom propuštanja planirane rutine vježbanja čini kontrolu ponašanja sve težom. U ovoj fazi vježbanje više ne služi samo kao kontrola raspoloženja nego i kako bi se izbjegli simptomi sustezanja. Iako je zadani sportski cilj postignut, osoba ne prestaje vježbati. Vježbanje koje se dosad odvijalo u društvu u ovom stadiju postaje individualna aktivnost. Nadalje, ponašanje postaje nediskriminativno, što znači da je osoba spremna na bilo koji drugi način vježbanja ako ne može odraditi svoju standardnu rutinu. Primjer za to jest ozljeda zgloba koja onemogućuje trčanje, pa se osoba odlučuje na vježbanje s utezima dok ne bude ponovno mogla trčati (Freimuth i sur., 2011).

\section{Četvrta faza: ovisnost o vježbanju}

Stalno povećavanje učestalosti i intenziteta vježbanja dovodi do stadija ovisnosti o vježbanju. Vježbanje postaje apsolutni prioritet $u$ životu osobe te se beskompromisno odvija na štetu svih ostalih obveza. Stalno gomilanje izravnih i sekundarnih negativnih posljedica dovodi do tercijarnih negativnih posljedica, koje se očituju u narušavanju svakodnevnoga funkcioniranja i nemogućnosti izvršavanja vlastitih obveza (Freimuth i sur., 2011).

Mjere samoprocjene razvijene su kako bi se utvrdili simptomi, uzroci i posljedice ovisnosti o vježbanju, a mogu se podijeliti $u$ jednodimenzionalne i višedimenzionalne (Symons Downs, Hausenblas i Nigg, 2004). Procjene osoba uglavnom se odnose na učestalost, trajanje i/ili intenzitet tjelesne aktivnosti ili broj godina bavljenja vježbanjem. Najčešće primjenjivan mjerni instrument $\mathrm{u}$ ispitivanju ovisnosti o vježbanju jest Skala ovisnosti o vježbanju (eng. Exercise Dependence Scale-21, EDS-21) autora Hausenblasa i Symons Downsa (2002b), koja je prevedena na hrvatski jezik i validirana za potrebe provedbe ovog istraživanja. Razlog široke primjene ove skale $u$ 
DRUŠ. ISTRAŽ. ZAGREB GOD. 27 (2018), BR. 4 STR. $713-733$

GARILOVIĆ, I., MACUKA, I.: OVISNOST O... istraživanjima jesu dobra psihometrijska obilježja i mogućnost kategorizacije sudionika $\mathrm{u}$ tri skupine, ovisno o postignutom rezultatu: skupinu bez simptoma; rizičnu skupinu vježbača koji nisu ovisni, ali iskazuju neke simptome ovisnosti; one ovisne o vježbanju s obzirom na znatan broj iskazanih simptoma. Kako dosad navedena skala nije primijenjena na hrvatskom uzorku, u ovom radu opisuje se provjera njezinih psihometrijskih svojstava.

U istraživanjima etioloških čimbenika ovisnosti o vježbanju često se od osobnih karakteristika ličnosti ističe perfekcionizam, koji se očituje u postavljanju pretjerano visokih osobnih standarda izvedbe. Istraživanja pokazuju kako je perfekcionizam značajno povezan s prekomjernim vježbanjem (Coen i Ogles, 1993; Flett i Hewitt, 2005) i odstupajućim navikama hranjenja (Halmi i sur., 2000; Haase, Prapavessis i Owen, 2002). Coen i Ogles (1993) prvi ističu važnost prepoznavanja dispozicijskoga perfekcionizma u objašnjavanju prekomjernoga vježbanja.

Treba istaknuti kako je prilikom procjenjivanja ovisnosti o vježbanju važno uzeti u obzir i druge probleme / poremećaje koji mogu biti prisutni. Posebnu pažnju zahtijeva prisutnost poremećaja hranjenja, kod kojeg osoba može na povećani kalorijski unos odgovoriti povećavanjem intenziteta vježbanja kako bi kontrolirala tjelesnu težinu (Freimuth i sur., 2011). Iako primarna ovisnost o vježbanju podrazumijeva nezavisnu ovisnost o samom vježbanju (pretjerivanje u smislu količine i intenziteta treninga), u dosadašnjim istraživanjima je veći interes pobuđivala tzv. sekundarna ovisnost o vježbanju, koja se razmatrala kao simptom poremećaja hranjenja. Poremećaji hranjenja često se javljaju zajedno s ovisnosti o vježbanju, odnosno čak $39 \%$ - $48 \%$ osoba s poremećajem hranjenja iskazuje i simptome ovisnosti o vježbanju (Hausenblas i Symons Downs, 2002a; Bamber, Cockerill i Carroll, 2000). O odsutnosti, tj. prisutnosti, poremećaja hranjenja ovisi ishod dijagnoze ovisnosti o vježbanju kao primarne ili sekundarne. Kako bi se osigurala ispravnost dijagnoze, valja pratiti određenu hijerarhiju prilikom dijagnosticiranja. Odbacivanje dijagnoze poremećaja hranjenja glavni je preduvjet za razmatranje postojanja primarne ovisnosti o vježbanju, a diferencijacija ovih dvaju poremećaja leži u krajnjem cilju ponašanja pojedinca. U slučaju primarne ovisnosti o vježbanju, tjelesna aktivnost je sama sebi svrha, dok kod sekundarne ovisnosti o vježbanju ona predstavlja kompenzacijsko ponašanje kojim se osobe suočavaju s brigama o težini i nezadovoljstvu tjelesnim izgledom (De Coverley Veale, 1987, 1995; Müller, Loeber, Söchtig, Te Wildt i De Zwaan, 2015). Istraživanja pokazuju kako su upravljanje tjeles- 
DRUŠ. ISTRAŽ. ZAGREB GOD. 27 (2018), BR. 4, STR. $713-733$

GARILOVIĆ, I., MACUKA, I.: OVISNOST O... nim izgledom i težinom glavni motivi vježbanja u ranijim stadijima poremećaja, a kasnije tu ulogu preuzima regulacija negativnog afekta (Bratland-Sanda i sur., 2011). Regulacija afekta kao motiv koji postaje sve važniji s iskustvom vježbanja utvrđena je i za samu ovisnost o vježbanju, kada se izuzmu poremećaji hranjenja (Hsiao i Thayer, 1998). Prekomjerno vježbanje značajno je povezano s većim odstupanjima u navikama hranjenja na uzorcima sudionika s poremećajem hranjenja (Shroff i sur., 2006), ali i na uzorcima zdravih sudionika (Elbourne i Chen, 2007).

$S$ obzirom na nedostatak adekvatnih mjernih instrumenata koji ispituju ovisnost o vježbanju, u ovom radu provjerila su se psihometrijska svojstva Skale ovisnosti o vježbanju (Exercise Dependence Scale-Revised- EDS-R/EDS-21; Hausenblas i Symons Downs, 2002b), prvi put adaptirane za primjenu na hrvatskom uzorku. Validacija ove skale na hrvatskom uzorku važan je metodološki doprinos području istraživanja ovisnosti o vježbanju i unaprjeđenju spoznaja o pojavnosti te korelatima ovisnosti o vježbanju. S obzirom na to da su rezultati ranijih istraživanja upozorili na važnu ulogu perfekcionizma kao osobine ličnosti i poremećaja hranjenja, cilj je ovog istraživanja bio ispitati relativan doprinos dimenzija perfekcionizma (osobni standardi, zabrinutost zbog pogrešaka, roditeljska očekivanja, roditeljska prigovaranja, sumnja u vlastitu izvedbu i organiziranost) i odstupajućih navika hranjenja (dijeta, bulimija i preokupacija hranom te oralna kontrola) u objašnjenju simptoma ovisnosti o vježbanju. Na temelju rezultata prijašnjih istraživanja očekuju se pozitivni doprinosi dimenzija perfekcionizma i navika hranjenja u objašnjenju ovisnosti o vježbanju. Odnosno, može se pretpostaviti kako će osobe koje iskazuju više razine perfekcionizma i odstupajućih navika hranjenja iskazivati i više simptoma ovisnosti o vježbanju.

\section{METODA}

\section{Sudionici istraživanja}

U istraživanju su sudjelovale 281 sudionice između 18 i 29 godina $(M=22,55, S D=2,70)$ s područja Hrvatske. Iako su online istraživanju pristupile ukupno 303 žene, njih $7 \%(N=22)$ izjavilo je kako se nikada ne bavi tjelesnom aktivnošću, pa su njihovi rezultati izuzeti iz daljnjih statističkih analiza. Na uzorku od 281 sudionica utvrđeno je kako se učestalo bave tjelesnom aktivnošću (5 i više puta na tjedan) 45 sudionica (16\%), 3 do 4 puta 98 sudionica ( $35 \%$ ), 1 do 2 puta 54 sudionica (19\%), 1 do 3 puta mjesečno 57 sudionica (17\%), a rijetko 37 sudionica (13\%). Osim toga 81 sudionica navodi da je učlanjena u teretanu $(29 \%)$ te da je većini primarni razlog vježbanja 
DRUŠ. ISTRAŽ. ZAGREB GOD. 27 (2018), BR. 4 STR. $713-733$

GARILOVIĆ, I., MACUKA, I.: OVISNOST O... zdravlje (162 sudionice - $57 \%$ ), zatim izgled (75 sudionica $27 \%$ ) i zabava / podizanje raspoloženja (44 sudionice - $16 \%$ ). Sudionice su odgovorile i na pitanje otvorenog tipa o vrsti tjelesne aktivnosti kojom se bave, a odgovori pokrivaju širok raspon tjelesnih aktivnosti, poput šetnje i brza hodanja, planinarenja te vožnje biciklom. Trčanje je vrlo čest odgovor, kao i vježbanje kod kuće uz pomoć programa vježbanja koji su dostupni online. Nadalje, sudionice navode i bavljenje fitness-programima (npr. aerobika, zumba, insanity, crossfit, pilates, joga) i sportovima (npr. plivanje, badminton, odbojka, pole dance, boks).

\section{Mjerni instrumenti}

Skala ovisnosti o vježbanju (Exercise Dependence Scale-21, EDS-21; Hausenblas i Symons Downs, 2002b)

Skala ovisnosti o vježbanju namijenjena je procjenjivanju prisutnosti simptoma ovisnosti o vježbanju. Autori navode kako je skala konstruirana na temelju kriterija za ovisnosti o supstancama Dijagnostičkog i statističkog priručnika za duševne poremećaje (DSM-IV, 1996), a sastoji se od 21 čestice koje su ravnomjerno raspodijeljene $\mathrm{u}$ sedam podskala. Svaka od podskala predstavlja jedan od kriterija, tj. simptoma ovisnosti o vježbanju, a to su: 1) tolerancija (3 čestice), koja označuje potrebu za povećanjem količine vježbanja u svrhu postizanja željenog učinka ili smanjivanje učinka dosadašnje količine vježbanja ("Stalno povećavam učestalost vježbanja kako bih došao / došla do željenih rezultata"), 2) efekti sustezanja (3 čestice), koji se odnose na negativne simptome poput anksioznosti ili iscrpljenosti u slučaju izostanka vježbanja ili vježbanje kako bi se ti simptomi izbjegli ("Vježbam kako se ne bih osjećao/la tjeskobno"), 3) efekti namjere (3 čestice), koji se odnose na vježbanje koje je intenzivnije ili dulje od planiranog ("Vježbam dulje nego što sam namjeravao/la"), 4) nedostatak kontrole (3 čestice), koji se odnosi na pojavu stalne želje za vježbanjem te nemogućnost njegove kontrole ("Ne mogu smanjiti intenzitet kojim vježbam"), 5) vrijeme (3 čestice), koje se velikim dijelom posvećuje planiranju vježbanja ("Većinu svog slobodnog vremena provodim vježbajući"), 6) smanjeno uključivanje u druge aktivnosti (3 čestice), koje često dovodi do konflikta zbog stavljanja vježbanja ispred drugih aktivnosti ("Razmišljam o vježbanju kad bih se trebao/la koncentrirati na školu / posao"), i 7) kontinuitet (3 čestice), koji označuje ustrajanje u vježbanju usprkos svemu, pa i tjelesnim ozljedama ("Vježbam unatoč ponavljanim tjelesnim problemima / ozljedama"). Osobe učestalost situacija sadržanih $\mathrm{u}$ tvrdnjama procjenjuju na ljestvici od 1 (nikada) do 6 (uvijek).

Prilikom procjene traži se prisutnost triju ili više simpto- 
DRUŠ. ISTRAŽ. ZAGREB GOD. 27 (2018), BR. 4, STR. $713-733$

GARILOVIĆ, I., MACUKA, I.: OVISNOST O... skalama, no u istraživanjima se češće rabi samo ukupan rezultat, pri čemu veći rezultat upućuje na veći broj prisutnih simptoma, odnosno veću opasnost od razvijanja ovisnosti o vježbanju. Osim intervalnih podataka (prosječni rezultati na ukupnoj skali i podskalama), primjena skale omogućuje i kategorizaciju sudionika u skupine (nominalni podaci). Pojedinci mogu biti smješteni u jednu od tri skupine: skupinu vježbača bez simptoma, skupinu neovisnih vježbača s nekim simptomima i rizičnu skupinu, tj. skupinu ovisnih vježbača. Osobe koje zadovolje kriterij za ovisnost na tri podskale ili više njih pripadaju skupini ovisnih o vježbanju. Procjena od pet ili šest za pojedinu tvrdnju, odnosno rezultat od 15 i više na pojedinoj podskali, smatra se indikatorom ovisnosti. Bodovanje tvrdnji u rasponu od tri do četiri (rezultat na podskalama između 7 i 14) uvjet je za klasifikaciju u skupinu sa simptomima u kojoj se nalaze osobe za koje postoji izgledna opasnost od razvijanja ovisnosti o vježbanju. Naposljetku, skupinu bez simptoma čine osobe koje tvrdnje procjenjuju u rasponu od jedan do dva (rezultat manji od 6 na podskalama).

Faktorska struktura skale provjerena je konfirmatornom faktorskom analizom (CFA), a za procjenu parametara uzet je algoritam maksimalne vjerojatnosti (engl. maximum likelihood estimation method-ML). Slaganje postavljenoga modela podacima utvrđeno je upotrebom apsolutnih i inkrementalnih indeksa pristajanja. Rezultati pokazuju dobro pristajanje pretpostavljenoga modela podacima $\chi^{2}=399,31, p<0,01, \mathrm{df}=168$, $\chi^{2} / \mathrm{df}=2,38, \mathrm{CFI}=0,94, \mathrm{TLI}=0,92, \mathrm{RMSEA}=0,07$ (C.I. $=$ $0,06-0,08)$, SRMR $=0,05$. Faktorska zasićenja pojedinih indikatora latentnim konstruktima statistički su značajna $(p<0,001)$, a kreću se u rasponu od 0,57 do 0,92 (popis čestica i faktorska zasićenja nalaze se u Prilogu 1).

Iako autori skale navode mogućnost izračuna rezultata na pojedinim podskalama (što može biti korisno u kliničkoj procjeni), $u$ istraživanjima ovisnosti o vježbanju u nekliničkoj populaciji predlažu izračunavanje ukupnog rezultata na skali. Kako bi se opravdalo izračunavanje ukupnog rezultata na skali, provjerena je latentna struktura skale. Potvrđeno je kako zasebne dimenzije ovisnosti o vježbanju (efekti sustezanja, kontinuitet, tolerancija, izostanak kontrole, smanjeno uključivanje $\mathrm{u}$ druge aktivnosti, vrijeme i efekti namjere) imaju značajna standardizirana zasićenja na faktoru višeg reda (u rasponu od 0,57 do 0,92 ), za koji se može pretpostaviti da predstavlja ovisnost o vježbanju. U skladu s tim, kao pokazatelj ovisnosti o vježbanju može se uzeti ukupni rezultat na Skali ovisnosti o vježbanju. Utvrđena je i zadovoljavajuća unutarnja konzistentnost izražena Cronbach-alphom cijele skale $(0,93)$. 
DRUŠ. ISTRAŽ. ZAGREB GOD. 27 (2018), BR. 4, STR. $713-733$

GARILOVIĆ, I., MACUKA, I.: OVISNOST O...
Višedimenzionalna skala perfekcionizma (Multidimensional Perfectionism Scale - Frost, MPS-F; Frost, Marten, Lahart i Rosenblate, 1990; adaptirana hrvatska verzija; Zubčić i Vulić-Prtorić, 2008)

Višedimenzionalna skala perfekcionizma sadrži 35 čestica koje omogućuju procjenu perfekcionizma kroz sljedeće podskale: 1) osobni standardi ("Ako si ne postavim najviše standarde, vjerojatno ću završiti kao drugorazredna osoba"), 2) zabrinutost zbog pogrešaka ("Ako djelomično pogriješim, to je jednako loše kao da sam pogriješila u cjelini"), 3) roditeljska očekivanja ("Moji roditelji su uvijek očekivali od mene da budem izvrsna"), 4) roditeljska prigovaranja ("Kao dijete kažnjavali su me ako ne bih savršeno učinila stvari"), 5) sumnja u vlastitu izvedbu ("Čak i kad nešto radim jako pažljivo, često osjećam da nije napravljeno dovoljno dobro") te 6) organiziranost ("Trudim se biti organizirana osoba"). Slaganje s pojedinom tvrdnjom iskazuje se na skali procjene od 5 stupnjeva (1 - potpuno neslaganje, 5 - potpuno slaganje). Krajnji rezultat može se dobiti za svaku pojedinu dimenziju perfekcionizma zbrajanjem pripadajućih čestica, a zbrajanjem rezultata na svim podskalama dobiva se ukupni rezultat na skali perfekcionizma. Dobiveni veći rezultat upućuje na višu razinu perfekcionizma. U ovom istraživanju utvrđeni Cronbach-alpha koeficijenti pouzdanosti pojedinih podskala kreću se u rasponu od 0,68 do 0,91 , a cijele skale 0,92 .

Upitnik navika hranjenja (The Eating Attitudes Test, EAT-26; Garner, Olmsted, Bohr i Garfinkel, 1982; adaptirana hrvatska verzija; Ambrosi-Randić i Pokrajac-Bulian, 2005)

Upitnik navika hranjenja najčešće je primjenjivani mjerni instrument za procjenu simptoma poremećaja hranjenja. Upitnik se sastoji od 26 čestica raspoređenih u tri podskale čije su čestice vezane uz 1) dijetu ("Izbjegavam hranu koja sadrži šećer"); 2) bulimiju i preokupaciju hranom ("Osjećam potrebu za povraćanjem nakon obroka"); te 3) oralnu kontrolu ("Usitnjavam hranu na manje zalogaje"). Sudionici procjenjuju tvrdnje na skali procjene od 1 do 6 (nikad, rijetko, ponekad, često, vrlo često i uvijek). Ukupan rezultat dobiva se zbrojem svih čestica i može biti u rasponu od 0 do 78 , a vrijednost jednaka ili veća od 20 upućuje na odstupajuće navike u hranjenju. $U$ ovom istraživanju utvrđeni Cronbach-alpha koeficijent za cijelu skalu iznosi zadovoljavajućih 0,77. Analiza pouzdanosti pojedinih podskala upitnika upućuje na zadovoljavajuću pouzdanost od 0,75 za podskalu dijeta i 0,67 za podskalu bulimija i preokupacija hranom. Međutim, zasebna podskala oralna kontrola nema zadovoljavajuću pouzdanost $(0,52)$ te nije uzeta u daljnju analizu rezultata. 


\section{Postupak istraživanja}

Istraživanje je provedeno online upitnikom od ožujka do rujna 2016. godine. Upitnik sastavljen uz pomoć web aplikacije Google Docs podijeljen je raznim grupama na društvenoj mreži facebook te je objavljen na stranici Istraži me (https://www.istrazime. com). S obzirom na to da je ovo istraživanje dio većeg istraživanja o navikama hranjenja kod žena, u uputi je bilo istaknuto da je istraživanje namijenjeno isključivo ženama. Sudjelovanje $\mathrm{u}$ istraživanju bilo je dobrovoljno i anonimno. Na početku upitnika naglašen je cilj istraživanja i uputa za svaki upitnik, a za ispunjavanje cjelokupnog upitnika u prosjeku je trebalo odvojiti oko 15 minuta.

\section{REZULTATI}

(1) TABLICA 1

Deskriptivni parametri skala i upitnika primijenjenih $\mathrm{u}$ istraživanju $(N=281)$

U Tablici 1 prikazani su različiti deskriptivni parametri svih mjernih instrumenata u ovom istraživanju $(N=281)$.

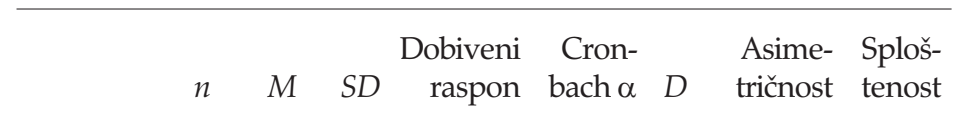

\begin{tabular}{|c|c|c|c|c|c|c|c|c|}
\hline \multicolumn{9}{|c|}{ Skala ovisnosti o vježbanju (EDS-21) } \\
\hline Efekti sustezanja & 3 & 9,92 & 3,88 & $3-18$ & 0,86 & $0,09^{*}$ & $-0,03$ & $-0,74$ \\
\hline Kontinuitet & 3 & 6,33 & 3,31 & $3-18$ & 0,83 & $0,16^{* *}$ & 1,09 & 0,68 \\
\hline Tolerancija & 3 & 9,02 & 3,82 & $3-18$ & 0,88 & $0,10^{*}$ & 0,33 & $-0,66$ \\
\hline Izostanak kontrole & 3 & 7,06 & 3,26 & $3-18$ & 0,81 & $0,14^{* *}$ & 0,95 & 0,79 \\
\hline $\begin{array}{l}\text { Smanjeno uključivanje } \\
\text { u druge aktivnosti }\end{array}$ & 3 & 5,71 & 3,60 & $3-18$ & 0,70 & $0,16^{* *}$ & 1,30 & 2,15 \\
\hline Vrijeme & 3 & 6,75 & 3,31 & $3-18$ & 0,89 & $0,15^{* *}$ & 1,08 & 0,94 \\
\hline Efekti namjere & 3 & 7,09 & 3,52 & 3-18 & 0,91 & $0,13^{* *}$ & 0,60 & $-0,46$ \\
\hline Ukupan rezultat & 21 & 51,89 & 17,26 & $21-124$ & 0,93 & $0,04^{*}$ & 0,46 & 0,52 \\
\hline \multicolumn{9}{|l|}{ Upitnik navika hranjenja (EAT-26) } \\
\hline Dijeta & 13 & 6,12 & 5,65 & $0-26$ & 0,75 & $0,16^{* *}$ & 1,10 & 0,48 \\
\hline Bulimija i preokupacija & & & & & & & & \\
\hline hranom & 6 & 1,48 & 2,55 & $0-11$ & 0,67 & $0,38^{* *}$ & 1,79 & 2,37 \\
\hline Oralna kontrola & 7 & 3,38 & 3,34 & $0-16$ & 0,52 & $0,17^{* *}$ & 1,19 & 1,09 \\
\hline Ukupan rezultat & 26 & 10,99 & 8,36 & $0-44$ & 0,77 & $0,13^{* *}$ & 1,08 & 0,85 \\
\hline \multicolumn{9}{|l|}{$\begin{array}{l}\text { Višedimenzionalna skala } \\
\text { perfekcionizma (MPS-F) }\end{array}$} \\
\hline Osobni standardi & 7 & 21,26 & 6,48 & $7-35$ & 0,86 & $0,06^{*}$ & $-0,01$ & $-0,74$ \\
\hline Zabrinutost zbog pogrešaka & 9 & 19,85 & 8,00 & $9-45$ & 0,90 & $0,11^{* *}$ & 0,72 & $-0,13$ \\
\hline Roditeljska očekivanja & 5 & 10,43 & 4,63 & $5-25$ & 0,81 & $0,13^{* *}$ & 0,69 & $-0,33$ \\
\hline Roditeljska prigovaranja & 4 & 7,97 & 3,54 & $4-20$ & 0,75 & $0,17^{* *}$ & 1,11 & 0,67 \\
\hline Sumnja u vlastitu izvedbu & 4 & 9,77 & 3,45 & $4-20$ & 0,68 & $0,08^{*}$ & 0,32 & $-0,27$ \\
\hline Organiziranost & 6 & 23,62 & 5,11 & $6-30$ & 0,91 & $0,11^{* *}$ & $-0,96$ & 1,01 \\
\hline Ukupan rezultat & 35 & 69,28 & 19,82 & $34-138$ & 0,92 & $0,07^{*}$ & 0,54 & $-0,03$ \\
\hline
\end{tabular}

Napomena: $n$ - broj čestica, $M$ - aritmetička sredina, $S D$ - standardna devijacija, $D$ - Kolmogorov-Smirnovljev test, ${ }^{*} p<0,05,{ }^{* *} p<0,01$. 
DRUŠ. ISTRAŽ. ZAGREB GOD. 27 (2018), BR. 4 STR. $713-733$

GARILOVIĆ, I., MACUKA, I.: OVISNOST O...

Vidi se kako Kolmogorov-Smirnovljev test (D) upućuje na značajno odstupanje rezultata od normalne distribucije na svim podskalama i ukupnom rezultatu Skale ovisnosti o vježbanju te upitnika perfekcionizma i navika hranjenja. Dobiveni rezultati pokazuju asimetriju, uz tendenciju grupiranja rezultata oko nižih vrijednosti. Kline (2011) kao alternativnu mogućnost utvrđivanja normalnosti distribucije navodi kako se uz vrijednosti manje od $+/-3$ za indeks asimetričnosti te +/-10 za indeks sploštenosti parametar normalnosti može smatrati zadovoljenim.

Kako je navedeno u opisu skale, podaci dobiveni Skalom ovisnosti o vježbanju omogućuju svrstavanje sudionica u skupine: skupinu bez simptoma, rizičnu skupinu s nekim simptomima i skupinu ovisnu o vježbanju. S obzirom na ukupan rezultat, $\mathrm{u}$ ovom istraživanju utvrđeno je da 118 sudionica $(41,99 \%)$ ne iskazuje simptome ovisnosti o vježbanju, njih 157 $(55,87 \%)$ ulazi u rizičnu skupinu s nekim izraženim simptomima, a samo 6 sudionica $(2,14 \%)$ postiže rezultat koji upućuje na ovisnost o vježbanju. S obzirom na to da je vrlo malen postotak sudionica postigao rezultat koji upućuje na značajnu prisutnost simptoma ovisnosti o vježbanju, u daljnjim analizama razmatrat će se samo ukupan rezultat na skali ovisnosti o vježbanju.

\section{Povezanost perfekcionizma i odstupajućih navika hranjenja s ovisnosti o vježbanju}

U Tablici 2 prikazani su koeficijenti bivarijatnih korelacija među svim mjerenim varijablama $(N=281)$.

Dobivene povezanosti među analiziranim varijablama niske su ili umjerene veličine te pokazuju da osobe sklonije perfekcionizmu i odstupajućim navikama hranjenja iskazuju i više simptoma ovisnosti o vježbanju. Zasebno razmatrane dimenzije perfekcionizma, osim roditeljskih prigovaranja $(\mathrm{r}=0,11)$, značajno su povezane s ovisnosti o vježbanju (od $r=0,15$ do $\mathrm{r}=0,36$ ). Preciznije, osobe koje su sklone postavljanju viših osobnih standarda, koje se više brinu zbog pogrešaka koje bi mogle učiniti, sumnjaju u vlastitu izvedbu te znatnu pažnju pridaju roditeljskim očekivanjima, a koje su organiziranije ujedno iskazuju više simptoma ovisnosti o vježbanju. Zasebno razmatrani odnosi odstupajućih navika hranjenja i ovisnosti o vježbanju upućuju na značajnu povezanost držanja dijete $(\mathrm{r}=$ $0,29)$ i ovisnosti o vježbanju, odnosno osobe sklonije držanju dijete iskazuju više simptoma ovisnosti o vježbanju. 


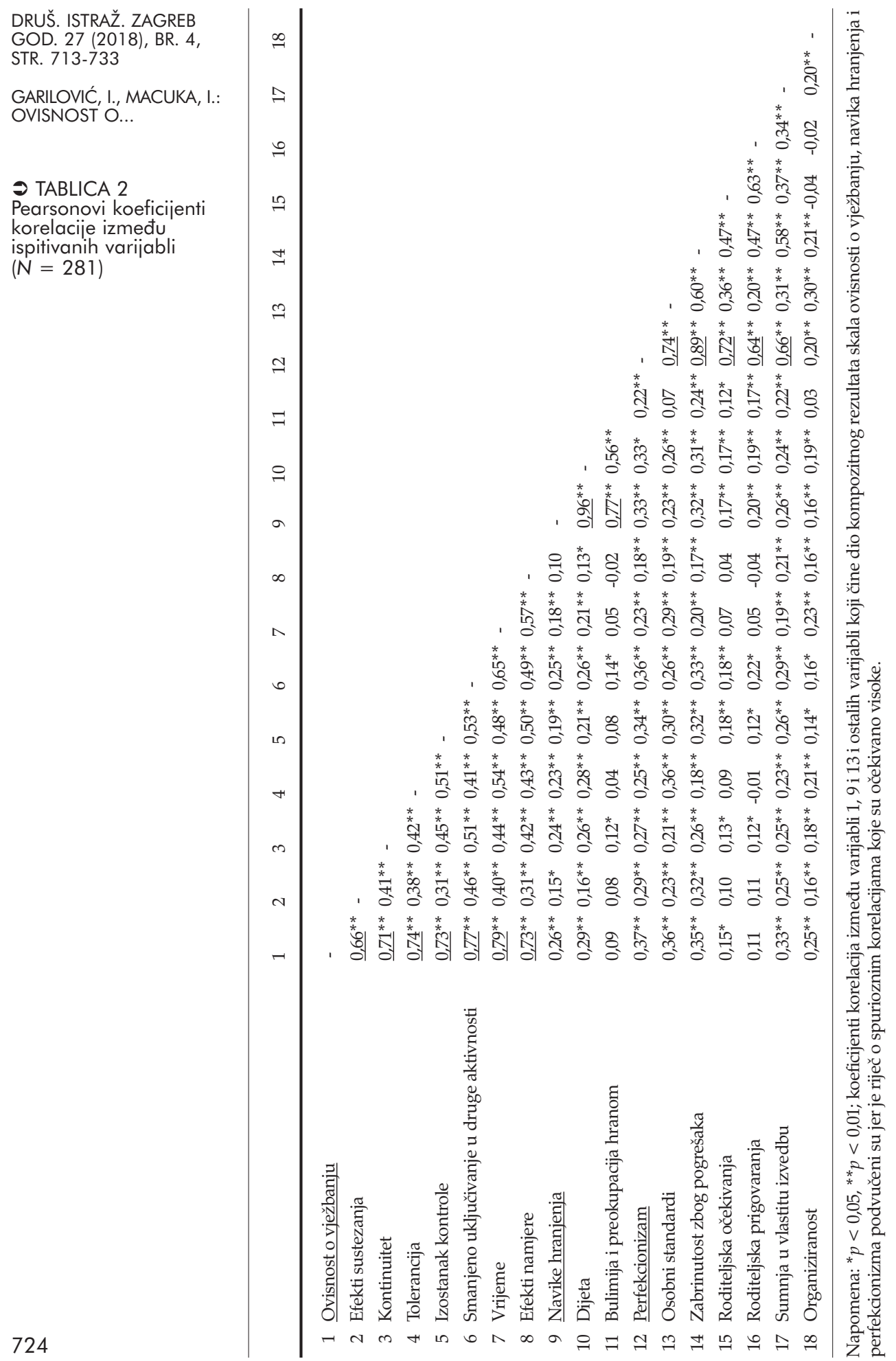




\section{Doprinos dimenzija perfekcionizma i odstupajućih navika hranjenja u objašnjenju ovisnosti o vježbanju}

Kako bi se provjerilo koje su značajne odrednice te u kojoj mjeri zasebno pridonose objašnjenju ovisnosti o vježbanju, provedena je hijerarhijska regresijska analiza (Tablica 3). U prvom koraku analize uvedene su osobine ličnosti - dimenzije perfekcionizma (osobni standardi, zabrinutost zbog pogrešaka, roditeljska očekivanja, roditeljska prigovaranja, sumnja u vlastitu izvedbu i organiziranost), a u drugom koraku stečene odstupajuće navike hranjenja (dijeta, bulimija i preokupacija hranom). Primjenom hijerarhijske regresijske analize može se kontrolirati nezavisan doprinos dviju skupina prediktora $\mathrm{u}$ objašnjenju ovisnosti o vježbanju.

$\rightarrow$ TABLICA 3

Doprinos dimenzija perfekcionizma i odstupajućih navika hranjenja u objašnjenju ovisnosti $\circ$ viežbanju $(N=281)$
Ovisnost o vježbanju

1. korak 2. korak

Prediktori $\beta \quad \beta$

1. korak: dimenzije perfekcionizma

Osobni standardi

$\begin{array}{ll}0,22^{* *} & 0,18^{* *} \\ 0,10 & 0,09 \\ -0,03 & -0,03 \\ -0,03 & -0,04 \\ 0,19^{* *} & 0,18^{* *} \\ 0,12 & 0,09\end{array}$

2. korak: odstupajuće navike hranjenja

Dijeta

$0,22^{* *}$

Bulimija i preokupacija hranom

$-0,10$

$\mathrm{R}^{2}$

$0,20^{* *}$

$0,23^{* *}$

Rkor $^{2}$

$0,18^{* *}$

$0,21^{* *}$

$0,02^{* *}$

Napomena: ${ }^{*} p<0,05,{ }^{* *} p<0,01, \mathrm{R}^{2}=$ ukupan doprinos objašnjenoj varijanci; $\Delta \mathrm{R}^{2}=$ doprinos pojedine grupe prediktora objašnjenoj varijanci; kor $^{2}=$ korigirani ukupni doprinos objašnjenoj varijanci.

Rezultati hijerarhijske regresijske analize pokazuju da dimenzije perfekcionizma u prvom koraku objašnjavaju ukupno $20 \%$ varijance ovisnosti o vježbanju. Pri tome su značajne zasebne doprinose ostvarile dimenzije osobnih standarda, sumnje u vlastitu izvedbu i organiziranosti. Rezultati pokazuju da osobe koje iskazuju visoke osobne standarde $(\beta=0,22)$ više sumnjaju u vlastitu izvedbu $(\beta=0,19)$ te su organiziranije $(\beta=0,12)$, iskazuju više razine ovisnosti o vježbanju. U drugom koraku uvedene odstupajuće navike hranjenja dodatno objašnjavaju značajnih $2 \%$ varijance kriterija, pri čemu je dijeta jedini značajni prediktor $(\beta=0,22)$, pokazujući pritom da osobe sklonije držanju dijete iskazuju više razine ovisnosti o vježbanju. Važno je istaknuti kako je uvođenjem drugoga se- 
DRUŠ. ISTRAŽ. ZAGREB GOD. 27 (2018), BR. 4, STR. $713-733$

GARILOVIĆ, I., MACUKA, I.: OVISNOST O...

\section{RASPRAVA}

ta varijabli dimenzija perfekcionizma organiziranost izgubila statističku značajnost $(\beta=0,09)$ vjerojatno zbog interkorelacija među varijablama. Zaključno, obuhvaćenim skupom svih prediktorskih varijabli može se ukupno objasniti $23 \%$ varijance ovisnosti o vježbanju.

Zbog učestalog isticanja pozitivnih učinaka redovita vježbanja u svakodnevnom životu istraživanja se rijetko bave proučavanjem negativnih posljedica koje ono može imati na tjelesno zdravlje i psihičku dobrobit pojedinca. U vremenu kada vježbanje zauzima status ne samo zdrave navike nego i ponašanja koje je u trendu, teško je jasno prepoznati ponašanje koje postaje štetno. Ovisnost o vježbanju upućuje na ekstremnu zaokupljenost tjelesnom aktivnošću, uz pridruženo zanemarivanje znakova iscrpljenosti, te ustrajanja u vježbanju čak i pri pojavi boli ili tjelesne ozljede (Hausenblas i Symons Downs, 2002b; Berczik i sur., 2014).

Dugo se problematika prekomjerna vježbanja proučavala kao dio simptomatologije poremećaja hranjenja, međutim nužno je istaknuti potrebu za distinkcijom primarne ovisnosti o vježbanju i sekundarne ovisnosti u kojoj se vježbanje pojavljuje uz odstupajuće navike hranjenja kao način kontrole tjelesnog izgleda. Upravo ideja o istraživanju odnosa ovih dvaju problema bila je pokretač ovog istraživanja i razlog provođenja istraživanja isključivo na ženama, koje češće nego muškarci imaju poremećaje hranjenja (Kelly-Weeder, Jennings i Wolfe, 2012). Specifičnije, cilj ovog istraživanja bio je ispitati u kakvu su odnosu ovisnost o vježbanju te perfekcionizam i odstupajuće navike hranjenja i kakav je njihov nezavisan doprinos objašnjenju ovisnosti o vježbanju. S obzirom na to da su na području Hrvatske istraživanja ovisnosti o vježbanju dosad bila izrazito rijetka (Vižintin i Barić, 2013; Škegro, 2011) - i zbog relativno novijega područja istraživanja, ali i nerazvijenosti mjernih instrumenata - u okviru ovog istraživanja prvi je put primijenjena Skala ovisnosti o vježbanju (Hausenblas i Symons Downs, 2002b). Provedena konfirmatorna faktorska analiza potvrđuje originalnu strukturu koju autori skale navode, skala sadrži 21 česticu raspoređenu u sedam faktora (simptomi sustezanja, kontinuitet, tolerancija, izostanak kontrole, smanjeno uključivanje $u$ druge aktivnosti, vrijeme i efekti namjere), a zadovoljavajuće psihometrijske karakteristike skale te pristajanje pretpostavljenog modela podacima upućuju na primjerenost daljnje primjene ovog instrumenta u budućim istraživanjima u Hrvatskoj. Podaci dobiveni ovom skalom omogućuju na temelju ukupnog rezultata svrstavanje sudionica u tri skupine - bez simptoma, rizičnu skupinu i skupinu koja iskazuje ovisnost o vježbanju. Rezultati ovog istraživanja pokazuju da potonjoj skupini pripada 
DRUŠ. ISTRAŽ. ZAGREB GOD. 27 (2018), BR. 4 STR. $713-733$

GARILOVIĆ, I., MACUKA, I.: OVISNOST O... samo $2 \%$ sudionica te pokazuju kako je ovisnost o vježbanju zapravo rijetka pojava, osobito kod žena, što je u skladu i s drugim istraživanjima (Bamber i sur., 2000; Bamber, Cockerill, Rodgers i Carroll, 2003). Gotovo 56 \% sudionica u ovom istraživanju navodi prisutnost nekih simptoma ovisnosti o vježbanju te ulaze u rizičnu skupinu, no kod $42 \%$ sudionica nisu prisutni nikakvi simptomi ovisnosti o vježbanju.

Ovo se istraživanje usmjerilo na ispitivanje uloge nekih karakteristika ličnosti (perfekcionizma) u objašnjenju ovisnosti o vježbanju. Dobiveni rezultati potvrđuju da su neke dimenzije perfekcionizma (osobni standardi i sumnja u vlastitu izvedbu) značajni prediktori ovisnosti o vježbanju. Općenito, osobe sklone perfekcionizmu imaju izraženu preokupaciju samoprezentacijom u smislu da su spremne ulagati velike napore kako bi se pred drugima pokazale u što boljem svjetlu. Ovaj neadaptivan obrazac ponašanja kod određenih vježbača može potaknuti prekomjerno vježbanje, što je potencijalno povezano s ovisnosti o vježbanju (Flett, Pole-Langdon i Hewitt, 2003). Na temelju dobivenih rezultata ovog istraživanja može se zaključiti kako visoki osobni standardi koji nisu lako ostvarivi te konstantna sumnja u vlastite sposobnosti ostvarivanja visokih ciljeva predstavljaju rizične čimbenike koji vježbanje mogu dovesti do razine ovisnosti. Ovaj je podatak u skladu s rezultatima prijašnjih istraživanja, koja također potvrđuju kako više simptoma ovisnosti o vježbanju iskazuju osobe izraženijega perfekcionizma (Hausenblas i Symons Downs, 2002a; Hausenblas i sur., 2004; Flett i Hewitt, 2005).

Nadalje, kad je riječ o odstupajućim navikama hranjenja (a njihov se nezavisan doprinos analizirao), dobiveni rezultati pokazuju kako su veća odstupanja u navikama hranjenja u obliku učestalijega držanja dijete značajni prediktori ovisnosti o vježbanju. Preciznije, osobe koje češće drže dijetu iskazuju više razine ovisnosti o vježbanju. Iako se može pretpostaviti kako je kod sudionica ovog istraživanja vježbanje povezano s reduciranjem unosa kalorija, važno je istaknuti kako sudionice $\mathrm{u}$ ovom istraživanju navode razne oblike tjelesnih aktivnosti kojima se koriste, a kod određenih vrsta vježbanja i sportova manja je tjelesna težina poželjna, tj. prediktivna za bolji uspjeh. Riječ je o tzv. "vitkim sportovima" (eng. lean sports), koji poseban naglasak stavljaju na estetsku vrijednost vitka tijela, a neki su od njih gimnastika, ples, ronjenje (Reinking i Alexander, 2005). Dakle, kod osoba koje se bave ovakvim oblicima tjelesne aktivnosti nastojanje kontroliranja tjelesne težine nije svrha sama po sebi nego i način postizanja boljeg uspjeha u određenoj aktivnosti, što bi upućivalo na primarnu ovisnost o vježbanju. Razlikovanje primarne i sekundarne ovisnosti o vježbanju predstavlja poseban izazov u istraživanjima, a za jasnu distinkciju vježbanja kao primarnoga ili sekundarnoga problema potrebna su daljnja istraživanja koja bi 
DRUŠ. ISTRAŽ. ZAGREB GOD. 27 (2018), BR. 4, STR. $713-733$

GARILOVIĆ, I., MACUKA, I.: OVISNOST O... uključivala detaljnije razmatranje i poremećaja prehrane i prethodno navedenih sportova nezavisno. Međutim, kao i u ovom istraživanju, i druga istraživanja potvrđuju povezanost izraženije prisutnosti simptoma ovisnosti o vježbanju i odstupajućih navika hranjenja (Lichtenstein, Christiansen, Elklit, Bilenberg i Støving, 2013; Zeulner, Ziemainz, Beyer, Hammon i Janka, 2016) te zaključno pokazuju da osobe koje su sklonije ovisnosti o vježbanju iskazuju i druge probleme, osobito na području navika hranjenja.

Neka od općih ograničenja i izazova u ovom području istraživanja odnose se na probleme distinkcije između količinski i vremenski pretjeranog vježbanja i ovisnosti o vježbanju. Model stadija ovisnosti o vježbanju (koji je detaljnije opisan u uvodnom dijelu rada) može pružiti jasnija objašnjenja, a novi mjerni instrument prikazan $\mathrm{u}$ radu predstavlja metodološki doprinos istraživanju ovoga konstrukta. Međutim, valja istaknuti: da bi se moglo govoriti o stvarnoj ovisnosti, potrebna je dijagnoza prema jasnim kriterijima za ovisnička ponašanja, a istraživanja koja rabe isključivo skale samoprocjene korisna su u identificiranju pojedinaca koji iskazuju rizična ponašanja (s obzirom na to da pružaju informacije isključivo o prisutnosti simptoma). S obzirom na to da se problematika prekomjerna vježbanja proučava uglavnom kao dio simptomatologije poremećaja hranjenja, u budućim istraživanjima preporučuje se usmjeravanje na razlikovanje primarne i sekundarne ovisnosti o vježbanju na kliničkim uzorcima. Za bolje razumijevanje nastanka i održavanja ovisnosti o vježbanju važna je i motivacija pojedinca. Istraživanja su dosad utvrdila kako se muškarci i žene znatno razlikuju u motivima za vježbanjem (u smislu da muškarce motivira društvena i natjecateljska komponenta vježbanja) (Markland i Hardy, 1993), dok žene češće kao motiv ističu reguliranje tjelesne težine (McDonald i Thompson, 1992). U budućim istraživanjima sigurno bi trebalo ispitati prevalenciju ovisnosti o vježbanju i kod muškaraca te razliku u motivima za vježbanje i etiološke čimbenike kod žena i muškaraca. S obzirom na to da su podaci prikupljeni online ispitivanjem, treba spomenuti i nedostatke, kao što su problemi nereprezentativnosti uzorka, niska stopa odaziva i odustajanje od istraživanja prije kraja te visoka razina anonimnosti koja onemogućuje otkrivanje obilježja ispitanika i sposobnost utjecaja na ispitanika. Iako postoje mnoga istraživanja koja proučavaju pozitivnu ulogu vježbanja, ovisnost o vježbanju još uvijek nije potaknula osjetniji interes istraživača u Hrvatskoj. Opisana Skala ovisnosti o vježbanju u ovom istraživanju te njezine zadovoljavajuće psihometrijske karakteristike čine je prikladnom za daljnju primjenu i istraživanja na većim uzorcima žena i muškaraca te profesionalnih sportaša u raznim sportovima, kako bi se unaprijedila spoznaja o pojavi ovisnosti o vježbanju. 


\section{PRILOG}

Rezultati konfirmatorne faktorske analize Skale ovisnosti o vježbanju (EDS 21) (N=281)

Čestice

Standardizirana faktorska zasićenja

Faktor 1. Efekti sustezanja

Vježbam kako se ne bih osjećala razdražljivo. $\quad 0,74$

Vježbam kako se ne bih osjećala tjeskobno. $\quad 0,81$

Vježbam kako se ne bih osjećala napeto. $\quad 0,91$

Faktor 2. Kontinuitet

Vježbam unatoč ponavljanim tjelesnim problemima/ozljedama. $\quad 0,75$

$\begin{array}{ll}\text { Vježbam i kad sam ozlijeđena. } & 0,77 \\ \text { Vježbam unatoč uč } & 0,85\end{array}$

Vježbam unatoč učestalim fizičkim problemima. $\quad 0,85$

Faktor 3. Tolerancija

Stalno povećavam intenzitet vježbanja kako bih došla do željenih rezultata. $\quad 0,79$

Stalno povećavam učestalost vježbanja kako bih došla do željenih rezultata. $\quad 0,91$

Stalno produljujem trajanje vježbe kako bih došla do željenih rezultata. $\quad 0,82$

Faktor 4. Nedostatak kontrole

$\begin{array}{ll}\text { Ne mogu skratiti trajanje vježbanja. } & 0,63\end{array}$

$\begin{array}{lr}\text { Ne mogu smanjiti učestalost vježbanja. } & 0,82\end{array}$

$\begin{array}{lr}\text { Ne mogu smanjiti intenzitet kojim vježbam. } & 0,84\end{array}$

Faktor 5. Smanjeno uključivanje u druge aktivnosti

Radije bih vježbala nego provodila vrijeme s obitelji/prijateljima. $\quad 0,74$

Razmišljam o vježbanju kad bih se trebala koncentrirati na školu/posao. $\quad 0,68$

Odabirem vježbanje kako ne bih morala provoditi vrijeme s obitelji/prijateljima. $\quad 0,57$

Faktor 6. Vrijeme

$\begin{array}{ll}\text { Puno vremena provodim vježbajući. } & 0,80\end{array}$

Većinu svog slobodnog vremena provodim vježbajući. $\quad 0,87$

Veliki dio svog vremena provedem vježbajući. $\quad 0,87$

Faktor 7. Efekti namjere

$\begin{array}{lr}\text { Vježbam dulje nego što sam namjeravala. } & 0,80\end{array}$

Vježbam dulje nego što sam očekivala. $\quad 0,92$

$\begin{array}{lr}\text { Vježbam dulje nego što sam planirala. } & 0,91\end{array}$

Napomena: Sva faktorska zasićenja značajna su uz $p<0,001$.

\section{LITERATURA}

Ambrosi-Randić, N. i Pokrajac-Bulian, A. (2005). Psychometric properties of the eating attitudes test and children's eating attitudes test in Croatia. Eating and Weight Disorders - Studies on Anorexia, Bulimia and Obesity, 10(4), 76-82. https://doi.org/10.1007/BF03327495

Američka psihijatrijska udruga (1996). Dijagnostički i statistički priručnik za duševne poremećaje (četvrto izdanje), međunarodna verzija. Jastrebarsko: Naklada Slap.

Bamber, D., Cockerill, I. M. i Carroll, D. (2000). The pathological status of exercise dependence. British Journal of Sports Medicine, 34(2), 125-132. https://doi.org/10.1136/bjsm.34.2.125 
DRUŠ. ISTRAŽ. ZAGREB STR. 713-733

GARILOVIĆ, I., MACUKA, I.: OVISNOST O... GOD. 27 (2018), BR. 4,

Bamber, D. J., Cockerill, I. M., Rodgers, S. i Carroll, D. (2003). Diagnostic criteria for exercise dependence in women. British Journal of Sports Medicine, 37(5), 393-400. https://doi.org/10.1136/bjsm.34.2.125

Berczik, K., Griffiths, M. D., Szabó, A., Kurimay, T., Kökönyei, G., Urbán, R. i Demetrovics, Z. (2014). Exercise addiction - the emergence of a new disorder. Australasian Epidemiologist, 21(2), 36-40. Dostupno na http://irep.ntu.ac.uk/id/eprint/26564.

Blaydon, M. J. i Lindner, K. J. (2002). Eating disorders and exercise dependence in triathletes. Eating Disorders, 10(1), 49-60. https://doi.org/ 10.1080/106402602753573559

Bratland-Sanda, S., Martinsen, E. W., Rosenvinge, J. H., Rø, Ø., Hoffart, A. i Sundgot Borgen, J. (2011). Exercise dependence score in patients with longstanding eating disorders and controls: The importance of affect regulation and physical activity intensity. European Eating Disorders Review, 19(3), 249-255. https://doi.org/10.1002/erv.971

Bratland-Sanda, S., Sundgot-Borgen, J., Rø, Ø., Rosenvinge, J. H., Hoffart, A. i Martinsen, E. W. (2010). Physical activity and exercise dependence during inpatient treatment of longstanding eating disorders: An exploratory study of excessive and non-excessive exercisers. International Journal of Eating Disorders, 43(3), 266-273. https://doi.org/ 10.1002/eat.20769

Coen, S. P. i Ogles, B. M. (1993). Psychological characteristics of the obligatory runner: A critical examination of the anorexia analogue hypothesis. Journal of Sport E Exercise Psychology, 15(3), 338-354. https://doi. org/10.1123/jsep.15.3.338

De Coverley Veale, D. M. W. (1995). Does primary exercise dependence really exist. Exercise addiction: Motivation for participation in sport and exercise, 1-5. Dostupno na http://www.veale.co.uk/wp-content/uploads/ 2010/10/14-Primary-Exercise-Dependence-1995.pdf.

De Coverley Veale, D. M. W. (1987). Exercise dependence. British Journal of Addiction, 82(7), 735-740. https://doi.org/10.1111/j.1360-0443.1987.tb 01539.x

Elbourne, K. E. i Chen, J. (2007). The continuum model of obligatory exercise: A preliminary investigation. Journal of Psychosomatic Research, 62(1), 73-80. https://doi.org/10.1016/j.jpsychores.2004.12.003

Flett, G. L. i Hewitt, P. L. (2005). The perils of perfectionism in sports and exercise. Current Directions in Psychological Science, 14(1), 14-18. https://doi. org/10.1111/j.0963-7214.2005.00326.x

Flett, G. L., Pole-Langdon, L. i Hewitt, P. L. (2003). Trait perfectionism and perfectionistic self-presentation in compulsive exercise. Toronto: York University.

Freimuth, M. (2008). Addicted?: Recognizing destructive behavior before it's too late. Lanham, MD, USA: Rowman \& Littlefield Publishers.

Freimuth, M., Moniz, S. i Kim, S. R. (2011). Clarifying exercise addiction: Differential diagnosis, co-occurring disorders, and phases of addiction. International Journal of Environmental Research and Public Health, 8(10), 4069-4081. https://doi.org/10.3390/ijerph8104069

Frost, R. O., Marten, P., Lahart, C. i Rosenblate, R. (1990). The dimensions of perfectionism. Cognitive Therapy and Research, 14(5), 449-468. 
DRUŠ. ISTRAŽ. ZAGREB GOD. 27 (2018), BR. 4, STR. $713-733$

GARILOVIĆ, I., MACUKA, I.: OVISNOST O...
Garner, D. M., Olmsted, M. P., Bohr, Y. i Garfinkel, P. E. (1982). The eating attitudes test: Psychometric features and clinical correlates. Psychological Medicine, 12(4), 871-878. https://doi.org/10.1017/S003329 1700049163

Haase, A. M., Prapavessis, H. i Owens, R. G. (2002). Perfectionism, social physique anxiety and disordered eating: A comparison of male and female elite athletes. Psychology of Sport and Exercise, 3(3), 209-222. https://doi.org/10.1016/S1469-0292(01)00018-8

Halmi, K. A., Sunday, S. R., Strober, M., Kaplan, A., Woodside, D. B., Fichter, M. i Kaye, W. H. (2000). Perfectionism in anorexia nervosa: Variation by clinical subtype, obsessionality, and pathological eating behavior. American Journal of Psychiatry, 157(11), 1799-1805. https://doi. org/10.1176/appi.ajp.157.11.1799

Haskell, W. L., Lee, I. M., Pate, R. R., Powell, K. E., Blair, S. N., Franklin, B. A. i Bauman, A. (2007). Physical activity and public health. Updated recommendation for adults from the American College of Sports Medicine and the American Heart Association. Circulation, 116(9), 1081-1093. doi:10.1161/CIRCULATION.107.185649

Hausenblas, H. A. i Symons Downs, D. (2002a). Exercise dependence: A systematic review. Psychology of Sport and Exercise, 3(2), 89-123. https://doi.org/10.1016/S1469-0292(00)00015-7.

Hausenblas, H. A. i Symons Downs, D. (2002b). How much is too much? The development and validation of the exercise dependence scale. Psychology \& Health, 17(4), 387-404. https://doi.org/10.1080/088704402 2000004894

Hsiao, E. T. i Thayer, R. E. (1998). Exercising for mood regulation: The importance of experience. Personality and Individual Differences, 24(6), 829-836. https://doi.org/10.1016/S0191-8869(98)00013-0

Kelly-Weeder, S., Jennings, K. M. i Wolfe, B. E. (2012). Gender differences in binge eating and behavioral correlates among college students. Eating and Weight Disorders, 17(3), 200-202. https://doi.org/10. 1007/BF03325348

Kline, R. B. (2011). Principles and practice of structural equation modeling (3rd ed). New York: Guilford Press Google Scholar.

Lejoyeux, M., Avril, M., Richoux, C., Embouazza, H. i Nivoli, F. (2008). Prevalence of exercise dependence and other behavioral addictions among clients of a Parisian fitness room. Comprehensive Psychiatry, 49(4), 353-358. https://doi.org/10.1016/j.comppsych.2007.12.005 Lichtenstein, M. B., Christiansen, E., Elklit, A., Bilenberg, N. i Støving, R. K. (2013). Exercise addiction: A study of eating disorder symptoms, quality of life, personality traits and attachment styles. Psychiatry Research, 215(2), 410-416. https://doi.org/10.1016/j.psychres.2013. 11.010

Markland, D. i Hardy, L. (1993). The exercise motivations inventory: Preliminary development and validity of a measure of individuals' reasons for participation in regular physical exercise. Personality and Individual Differences, 15(3), 289-296. https://doi.org/10.1016/0191-88 69(93)90219-S 
DRUŠ. ISTRAŽ. ZAGREB GOD. 27 (2018), BR. 4, STR. $713-733$

GARILOVIĆ, I., MACUKA, I.: OVISNOST O...
McDonald, K. i Thompson, J. K. (1992). Eating disturbance, body image dissatisfaction, and reasons for exercising: Gender differences and correlational findings. International Journal of Eating Disorders, 11(3), 289-292. https://doi.org/10.1002/1098-108X(199204)11:3<289::AIDEAT2260110314>3.0.CO;2-F

Modoio, V. B., Antunes, H. K. M., Gimenez, P. R. B. D., Santiago, M. L. D. M., Tufik, S. i Mello, M. T. D. (2011). Negative addiction to exercise: Are there differences between genders? Clinics, 66(2), 255-260. https://doi.org/10.1590/S1807-59322011000200013

Mónok, K., Berczik, K., Urbán, R., Szabo, A., Griffiths, M. D., Farkas, J. ... i Demetrovicz, Z. (2012). Psychometric properties and concurrent validity of two exercise addiction measures: A population wide study. Psychology of Sport and Exercise, 13(6), 739-746. https://doi.org/ 10.1016/j.psychsport.2012.06.003

Müller, A., Loeber, S., Söchtig, J., Te Wildt, B. i De Zwaan, M. (2015). Risk for exercise dependence, eating disorder pathology, alcohol use disorder and addictive behaviors among clients of fitness centers. Journal of Behavioral Addictions, 4(4), 273-280. https://doi.org/10.1556/ 2006.4.2015.044

Reinking, M. F. i Alexander, L. E. (2005). Prevalence of disordered-eating behaviors in undergraduate female collegiate athletes and non-athletes. Journal of Athletic Training, 40(1), 47-51. Dostupno na https://www.ncbi.nlm.nih.gov/pmc/articles/PMC1088345/

Shroff, H., Reba, L., Thornton, L. M., Tozzi, F., Klump, K. L., Berrettini, W. H., Brandt, H. ... i Bulik, C. M. (2006). Features associated with excessive exercise in women with eating disorders. International Journal of Eating Disorders, 39(6), 454-461. https://doi.org/10.1002/eat.20247

Symons Downs, D., Hausenblas, H. A. i Nigg, C. R. (2004). Factorial validity and psychometric examination of the exercise dependence scale-revised. Measurement in Physical Education and Exercise Science, 8(4), 183-201. https://doi.org/10.1207/s15327841mpee0804_1

Szabo, A., Griffiths, M. D. i Demetrovics, Z. (2016). Exercise addiction. U V. R. Preedy (Ur.), Neuropathology of drug addictions and substance misuse, Volume 3: General processes and mechanisms, prescription medications, caffeine and areca, polydrug misuse, emerging addictions and non-drug addictions (str. 984-992). Academic Press. https://doi.org/10.1016/ B978-0-12-800634-4.00097-4

Škegro, M. (2011). Sportaši i rekreativni vježbači: ovisnost o vježbanju. (Diplomski rad). Kineziološki fakultet, Zagreb.

Vižintin, M. i Barić, R. (2013). Ovisnost o vježbanju - spolne razlike. Hrvatski športsko medicinski vjesnik, 28(2), 71-80. Dostupno na http://hrcak. srce.hr/file/184295.

Zeulner, B., Ziemainz, H., Beyer, C., Hammon, M. i Janka, R. (2016). Disordered eating and exercise dependence in endurance athletes. Advances in Physical Education, 6(2), 76-87. https://doi.org/10.4236/ape.20 16.62009

Zubčić, T. i Vulić-Prtorić, A. (2008). Multidimenzionalna skala perfekcionizma (MPS-F). U Z. Penezić i sur. (Ur.), Zbirka psihologijskih skala $i$ upitnika - Svezak 4 (str. 23-35). Zadar: Sveučilište u Zadru. 
DRUŠ. ISTRAŽ. ZAGREB GOD. 27 (2018), BR. 4 STR. $713-733$

GARILOVIĆ, I., MACUKA, I.: OVISNOST O...

\section{Exercise Dependence - The Role of Perfectionism and Disordered Eating}

Ivana GARILOVIĆ

Department of Human Resources, Kutjevo d.d., Kutjevo

Ivana MACUKA

Department of Psychology, University of Zadar, Zadar

Despite the physical and psychological benefits of exercise, recent evidence has been gathered on the downsides of this healthy habit in the form of exercise dependence. Exercise dependence is an uncontrolled urge for exercising and satisfying that urge becomes the ultimate goal in everyday life and, consequently leads to the loss of beneficial effects of exercise. This study contains validation of the Exercise Dependence Scale (Hausenblas \& Symon Downs, 2002b) used for the first time on a Croatian sample for measuring exercise dependence symptoms. In an online conducted research 281 women participated, mean age of 22 years $(S D=2.70)$. The aim of this study was to examine the contribution of perfectionism and disordered eating in explaining exercise dependence symptoms. The conducted analyses identified personal standards, doubt about actions, and dieting as significant individual predictors for exercise dependence. More precisely, participants with higher personal standards, more doubts about their actions, and those who often engage in dieting tend to experience more exercise dependence symptoms. Perfectionism dimensions and disordered eating aspects explained $23 \%$ of the exercise dependence variance.

Keywords: exercise dependence, perfectionism, disordered eating

\section{(c) (1) (8)}

Međunarodna licenca / International License:

Imenovanje-Nekomercijalno / Attribution-NonCommercial 